International Journal of Current Advanced Research

ISSN: O: 2319-6475, ISSN: P: 2319 - 6505, Impact Factor: SJIF: 5.995

Available Online at www.journalijcar.org

Volume 6; Issue 3; March 2017; Page No. 2652-2653

DOI: http://dx.doi.org/10.24327/ijcar.2017.2653.0066

Research Article

\title{
MORPHOMETRIC ANALYSIS OF HYPOPHYSEAL FOSSA IN SOUTH INDIAN DRY ADULT HUMAN SKULLS
}

\section{Simon Chouhan*}

Department of Anatomy Saveetha Dental College and Hospitals, Saveetha University, Chennai-600077

\begin{tabular}{|c|c|}
\hline A R T I C L E I N F O & A B S T R A C T \\
\hline Article History: & $\begin{array}{l}\text { Aim: To examine the anatomy of hypophyseal fossa, its morphological feauturesand } \\
\text { dimensions. }\end{array}$ \\
\hline Received $5^{\text {th }}$ December, 2016 & Objective: To measure the dimensions of hypophyseal fossa and to examine it. \\
\hline Received in revised form $8^{\text {th }}$ January, 2017 & Background: It is a depression in the sphenoid lodging the pituitary gland called also \\
\hline Accepted $11^{\text {th }}$ February, 2017 & pituitary fossa.The pituitary is often called the 'master gland' because it controls the \\
\hline Published online $28^{\text {th }}$ March, 2017 & $\begin{array}{l}\text { secretion of most of the hormones of the body. The sella turcicais located in the sphenoid } \\
\text { bone behind the Chiasmatic groove and tuberculumsellae. }\end{array}$ \\
\hline Key words: & Reason: This study will be helpful for neurosurgeons. \\
\hline
\end{tabular}

Sellaturcica, pituitary fossa, sphenoid

bone,dorsum sella.

Copyright $\bigcirc 2017$ Simon Chouhan. This is an open access article distributed under the Creative Commons Attribution License, which permits unrestricted use, distribution, and reproduction in any medium, provided the original work is properly cited.

\section{INTRODUCTION}

The sella turcica (Latin for Turkish seat) is a saddle-shaped depression in the body of the sphenoid bone of the human skull and of the skulls of-other hominids including chimpanzees, $x$ orangutans, and gorillas. (1). Since the sella turcica forms a bony caudal border for the pituitary gland, a pituitary tumour usually extends upward in the rostral direction into the suprasellar region. This can result in compression of the optic chiasma which lies on top of the pituitary, enveloping the pituitary stalk. Compression of the optic chiasma can lead to bitemporal hemianopsia, and, when there is no relevant trauma, this clinical finding is pathognomonic for a pituitary tumor.Some pituitary adenomas can extend inferiorly, growing downward and invading the sphenoid bone and cavernous sinus.(2). Sella turcica is also usually used as a reference point with nasion to establish the base of the skull in cephalometric analysis. This is commonly done prior to orthodontic treatment. (3). According to classical anatomical texts (for example, $[4,5,6])$, the hypophyseal fossa is a cavity formed at the upper surface of the body of the sphenoid bone between the tuberculumsellae and the dorsum sella.

\section{MATERIALS AND METHODS}

The morphometric analysis was performed on 30 dry adult human skulls. The study was conducted in the department of Anatomy Saveetha Dental College and Hospitals, chennai, Tamil Nadu.

\section{*Corresponding author: Simon Chouhan}

Department of Anatomy Saveetha Dental College and

Hospitals, Saveetha University, Chennai-600077
The length and breadth was measured using digital vernier callipers $(0.01 \mathrm{~mm})$. The height was measured using scale. The measurements were taken twice to avoid errors.

\section{RESULTS AND DISCUSSION}
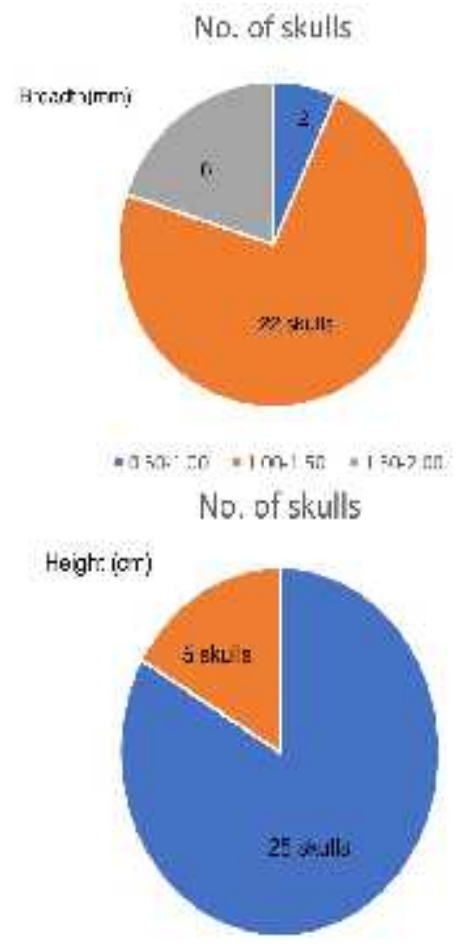

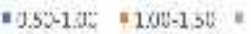




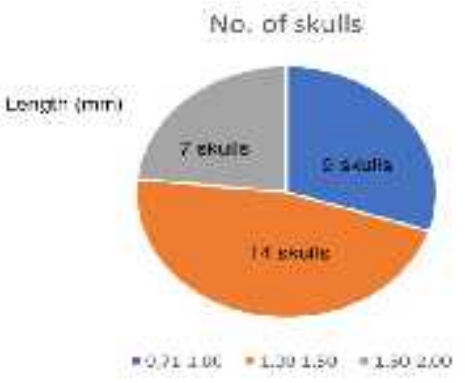

The results calculated are as follows. Length was measured. 7 people had length between 1.50-2.00, 9 had between 0.71 1.00 and 14 had between 1.00-1.50.Breadth was measured .2 had it between 0.50-1.00,22 had between 1.00-1.50 and 6 had between 1.50-2.00. The height was also measured. 25 had it between $0.5-1.00$ and 5 had it between 1.00-1.50.Thus it shows us the following parameters. The dimensions of the sella turcica, namely its length, width, depth and volume, have been mea- sured by many other authors $(7,8,9,10)]$. The variability of the reported results is impressive. Thus the length of the sella varies between $5 \mathrm{~mm}$ and $16 \mathrm{~mm}$, the width between $9 \mathrm{~mm}$ and $18 \mathrm{~mm}$, the depth between $4 \mathrm{~mm}$ and 13 $\mathrm{mm}$.

\section{CONCLUSION}

The morphometric study of hypophyseal fossa with above mentioned parameters is very useful for neurosurgeons. It is also useful for orthodontists, as when growth changes the orthodontic treatment results are to be evaluated.

\section{References}

1. Mancall, Elliott L.; Brock, David G., eds. (2011). "Cranial Fossae". Gray's Clinical Anatomy. Elsevier Health Sciences. p. 154. ISBN 9781437735802.

2. KnospE, Steiner E, Kitz K, et al. Pituitary adenomas with invasion of the cavernous sinus space: a magnetic resonance imaging classification compared with surgical findings. Neurosurgery. 1993 Oct; 33(4):6107; discussion 617-8. PMID 8232800

3. Proffit, William R. Contemporary Orthodontics, 4th Edition. C.V. Mosby, 122006. 6.5.2.1). vbk:978-0-32304046-4\#outline(6.5.2.1)

4. Johnston TB, Whillis J (eds.) (1944) Gray's anatomy. 28. Longmans, Green and Co., London, p. 970.

5. Paturet G (1951) Taité d' AnatomieHumaine. Tome I. Masson et $\mathrm{C}$,

6. P, Charpy A, Cunéo B (1908). Abrégé d'Ana- tomie. Tome I. Mas.

7. Camp JD (1924) the normal and pathologic anatomy of the sella turcica as revealed by roentgenograms. Am J Roentgenol Rad TherNucl Med, 12: 143-156.

8. DichoroG, Nelson KB (1962) the volume of the sella turcica. Am J Roentgenol Rad TherNucl Med, 87: 989-1008 .

9. RennWH, Rhoton AL (1975) Microsurgical anatomy of the sellar region. J Neurosurg, 43: 288-298.

10. TaverasJM, Wood EH (1964) Diagnostic Neuroradiology, Williams \& Wilkins, Baltimore, pp. 100-104.

Please cite this article in press as:

Simon Chouhan (2017), Morphometric Analysis Of Hypophyseal Fossa In South Indian Dry adult human skulls, International Journal of Current Advanced Research, 6(3), pp. 2652-2653.

http://dx.doi.org/10.24327/ijcar.2017. 2653.0066 